\title{
Dar novos mundos ao mundo
}

\section{Ana Campos}

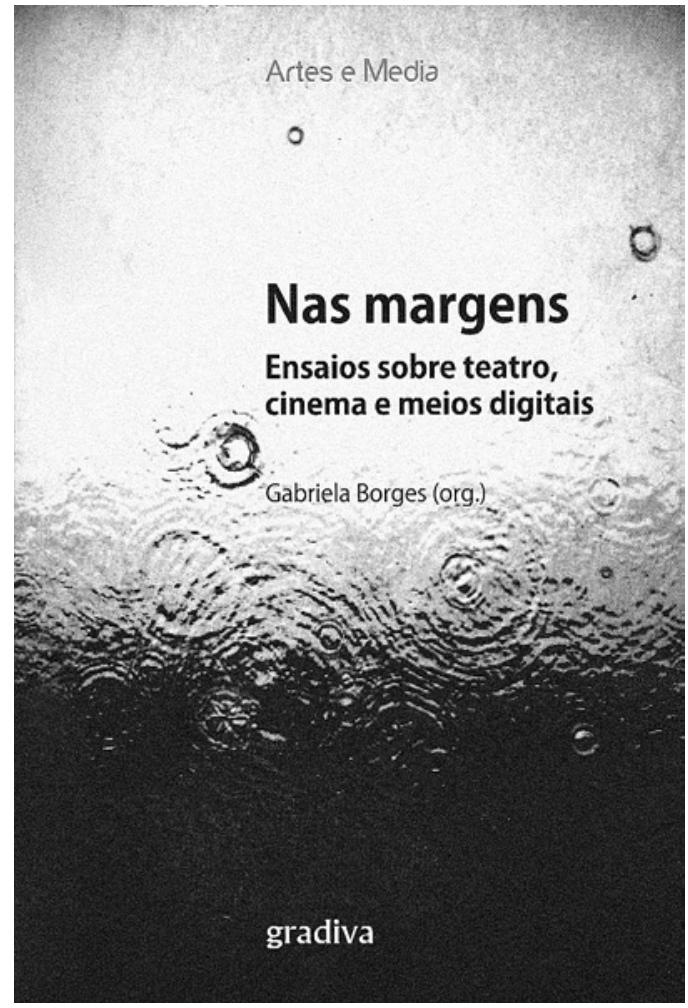

Gabriela Borges (org.), Nas margens: Ensaios sobre teatro, cinema, e meios digitais. Lisboa: Gradiva/Centro de Investigação em Artes e Comunicação, Col. Artes e Media ${ }^{\circ} 1,1^{\text {a }}$ ed., Março, 2010, 216 pp.

Ainda que não esteja ainda completamente reconhecida, nos meios académicos mais conservadores, a emergência de uma série de novas tecnologias veio criar géneros hibridos no campo da criação artística, quebrando as barreiras estanques que dividiam teatro, cinema e meios digitais. Esta coletânea de ensaios debruça-se sobre as questões que tais géneros levantam em termos conceptuais e que mecanismos de análise devem ser convocados para os compreender. A publicação, surgida na sequência do I Simpósio Internacional em Comunicação, Cultura e Artes, organizado pelo Centro de Investigação em Artes e Comunicação (da Universidade do Algarve), regista as comunicações ai apresentadas, bem como outras colaborações avulsas.

A diversidade dos temas abordados, submetidos, contudo, ao denominador comum da interligação entre as diferentes artes que os meios digitais actualmente permitem, torna a obra muito abrangente, pelo que a edição optou pela distinção entre aqueles que se centram nas questões teatrais, os que dizem respeito ao cinema, os que abordam as questões da autoria e ainda aqueles que versam especificamente os meios digitais. Alguns dos ensaios, no entanto, apesar do seu inquestionável valor para os estudiosos das questões que abordam, fogem ao tema da obra, pelo que não os observaremos aqui. É o caso das reflexões de António Branco sobre o conceito de "escola de teatro", de David Antunes sobre a necessidade de elaboração de uma política cultural sustentada para o teatro português, de José Paulo Pereira sobre a obra de Brecht, de Hudson Moura sobre o cinema da diáspora no Canadá e de Josette Monzani sobre o processo de trabalho de Glauber Rocha.

Erick Felinto, no seu ensaio "Think Different: os estilos de vida digitais e a cibercultura como expressão cultural", expõe claramente o princípio que preside aos restantes textos: "Comunicação, cultura e tecnologia formam uma tríade inseparável e indispensável para o entendimento de nossa situação contemporânea" (p. 166). Esse entendimento passa, na visão da maioria dos ensaístas, pela tentativa exaustiva de (re)conhecer ferramentas tradicionais, como a análise do processo de construção narrativa, nas novas realidades com que a tecnologia nos surpreende de forma a torná-las mais compreensiveis e consequentemente mais socialmente integradas. Ensaio fundamental para a compreensão dos processos que sustentam a identidade e a interacção virtual, assinado por Bruno Silva, é "Relações virtuais: Da sedução de Baudrillard à representação de papéis no Second Life". Aqui o autor analisa as interacções no espaço virtual, em particular no Second Life, partindo da ideia de que esse espaço de anonimato, experimentação e liberdade absoluta funciona como um laboratório de auto-conhecimento e como uma nova forma de relação do homem com o
Ana Campos é doutoranda em Estudos de Teatro, professora do ensino secundário e investigadora do Centro de Estudos de Teatro da Faculdade de Letras da Universidade de Lisboa. 
mundo, sobrepondo-se ao próprio espaço e tempo e criando a ilusão de um autocontrolo - quase absoluto do seu corpo e do seu comportamento. 0 autor detecta nestes universos paralelos a procura generalizada da cultura contemporânea para ficcionar a vida. Vai mais longe ainda ao analisar um elemento fundamental para o entendimento da questão: o papel das emoções na recepção da obra artística. Tal como Nelson Zagalo nota ao reflectir sobre o suspense nos videojogos, a capacidade que o virtual dá ao indivíduo de se enamorar pela emoção em si e não por um objecto em particular é a chave, ainda não suficientemente estudada, para o entendimento das potencialidades artísticas no e através do mundo virtual. Zagalo explora a construção do suspense em jogos de video, partindo da premissa que o desenvolvimento assenta na personagem e não em sequências narrativas. Cabendo ao jogador procurar respostas através da sua personagem/avatar, este é, no fim, premiado com o fechar do círculo narrativo e com a sensação gratificante de ser o espectador, personagem e realizador de uma história que conseguiu construir até ao final. No meio, fica um hábil manipular da tensão do jogador conseguido através do uso inteligente do suspense como modo de apresentar a informação.

Ao analisar a obra de Samuel Beckett, Gabriela Borges em "As cabeças falantes do universo beckettiano: Uma análise da transcrição do texto teatral That Time" debruçase sobre o projecto Beckett on Film, levado a cabo em 1999 pela televisão pública irlandesa RTÉ, o Channel 4 britânico e o Irish Film Board, com o consentimento do
Beckett Estate. Esta transposição de linguagens levanta importantes questões sobretudo quando se trata de um autor que as condenava liminarmente por considerar o meio um elemento estético intrínseco à obra, impossivel de ser explorado noutro meio. Contudo, processos como o da fragmentação de partes do corpo das personagens foram pelo autor levados ao limite na televisão e depois transpostos para o teatro, num imbricar de manifestações artísticas que subverte as fronteiras estanques que tínhamos como certas. Para além destas possibilidades plásticas, o filme tem na sua natureza uma característica que o teatro não possui: a capacidade de permanecer como objecto e de alguma forma poder perpetuar o próprio trabalho teatral do criador ainda que dentro de outra forma-prisão. Saber até que ponto esta transposição permite criar novos objectos artísticos e, em última análise, determinar quem é o seu criador são algumas das questões que a autora se coloca e nos coloca.

A intrusão das novas linguagens na criação artística, a reconfiguração dos processos criativos em consequência desta intrusão, as transformações que implicam na sua recepção e a dificuldade de inserir os produtos artísticos dai resultantes nas convencionais categorias artísticas tornam muito urgente a necessidade de uma reflexão profunda sobre esta realidade que convoque o pensamento de todos os que participam no debate artístico de forma a conseguir inseri-las no discurso cultural atendendo, contudo, ao hibridismo que as caracteriza e às diferentes artes que convocam. 